\title{
Gruppelærerdagen - kvalitet fra første undervisningstime
}

\author{
M. T. P. Beerepoot ${ }^{1,2}$ og H. L. Huru ${ }^{3,4}$ \\ ${ }^{1}$ Institutt for kjemi, ${ }^{2}$ Ressurssenter for undervisning, laring og teknologi, ${ }^{3}$ Institutt for matematikk og \\ statistikk, ${ }^{4}$ Institutt for laererutdanning og pedagogikk, UiT Norges arktiske universitet
}

\begin{abstract}
SAMMENDRAG: En stor del av undervisningen i realfagene ved norske universiteter blir utført av stipendiater eller studenter fra tidligere kull. Fokus på opplæring av denne gruppen undervisere kan bidra til en positiv effekt på undervisningskvalitet og studentenes læring. Det varierer imidlertid fra institusjon til institusjon om det finnes en slik type opplæring og omfang og kvalitet på denne opplæringen kan avhenge av fakultet, institutt, emne og emnelederen. Vi har satt oss som mål å organisere et enkelt opplæringstilbud for ferske og mer erfarne gruppelærere på vårt fakultet for å bidra til trygghet og kvalitet fra første undervisningstime. Vi drøfter ulike temaer vi har mott $\mathrm{i}$ organisering av dagene, spesielt relevans for ulike fag og ulike undervisningsoppgaver, språk og omfang på opplegget og rollen som dagen har i pedagogisk opplæring og videreutvikling hos gruppelærerne. Vi belyser temaene ut fra internasjonal litteratur på feltet, evalueringsresultater fra gruppelærerdagene og våre egne erfaringer. Vi håper at dette bidraget kan inspirere andre til å ha mer fokus på opplæring av gruppelærere og gi verdifull innsikt til organisering av opplæringen. Samtidig ønsker vi å vise at dette ikke nødvendigvis må bli ressurskrevende for å utgjøre en forskjell for studentene, for gruppelærerne, og forhåpentligvis også for undervisningskvaliteten på fakultetet som helhet.
\end{abstract}

\section{INNLEDNING}

Ved norske universiteter er det innen realfagene vanlig at en stor del av undervisningen blir utført av stipendiater eller studenter fra tidligere kull. Disse har som regel ikke hovedansvar for undervisningen i et emne, men tildeles ansvaret for et bestemt område av undervisningen som for eksempel undervisning i mindre grupper, oppgaveregning, vurdering av innleveringer eller undervisning på laboratoriet eller i felt. Vi velger å bruke begrepet gruppelarer for studenter eller stipendiater med slike undervisningsoppgaver. Andre begreper som ofte brukes om (mer eller mindre) det samme er læringsassistent, Øvings- eller hjelpelærer, vit. ass. og på engelsk (graduate) teaching assistant (GTA/TA). Selv om gruppelærere ofte er de som har tettest kontakt med studentene og dermed er i en unik posisjon til å $\emptyset \mathrm{ke}$ kvalitet på studentenes læring, har det vært lite fokus på denne gruppen i arbeid med kvalitetsutvikling i høyere utdanning [1,2].

Fokus på opplaring av gruppelærere kan bidra til en positiv effekt på undervisningskvalitet og dermed på studentenes læring [3]. Det varierer imidlertid fra institusjon til institusjon om det finnes opplæring for denne gruppen undervisere, og omfang og kvalitet på denne opplæringen kan avhenge av fakultet, institutt, emne og emnelederen. Opplæring av gruppelærere kan ta mange ulike former og kan ha svært ulikt omfang, alt fra uformell oppfølging på det enkelte emne eller institutt til formalisert opplæring over flere semestre som et sentralt tilbud fra universitetet. Imidlertid anbefaler flere at komponenter av opplæringen er fagnær [4,5], i vårt tilfelle med økt relevans for naturvitenskap og teknologi.

UiT Norges arktiske universitet har over et par tiår hatt et formelt opplæringstilbud for undervisere i faste stillinger. Dette har etter hvert blitt supplert med et eget kursopplegg for ph.d.-studenter. Imidlertid har studenter med undervisningsoppgaver til nå ikke hatt et slikt tilbud, verken sentralt på universitetet eller på Fakultet for naturvitenskap og teknologi. Eksempelvis har NTNU derimot et obligatorisk opplæringssystem for læringsassistenter (LAOS) hvor både universitetspedagoger og fagmiljøene bidrar til å kvalifisere disse til ulike undervisningsoppgaver [6,7].

Vi har satt oss som mål å organisere et enkelt opplæringstilbud for gruppelærere på vårt fakultet for å bidra til trygghet og kvalitet fra første undervisningstime hos gruppelærere. Vi mener at vi gjennom god opplæring og $\varnothing \mathrm{kt}$ trygghet kan bidra til at underviserne er mer bevisst sin rolle i utdanningen og tar bedre valg i egen undervisning - noe som på kort og lang sikt vil kunne føre til økt undervisningskvalitet.

I dette bidraget beskriver vi tilbudet (som vi har kalt Gruppelaererdagen), evalueringsresultater for utbytte av dagen og i hvilken grad gruppelærerne selv umiddelbart rapporterer følelse av trygghet. Vi drøfter ulike temaer vi har møtt i organisering av dagene, herunder relevans for ulike fag og ulike 
undervisningsoppgaver; språk og omfang på opplegget; og rollen som dagen har i pedagogisk opplæring og videreutviklingen til gruppelærerne. Vi belyser temaene ut fra internasjonal litteratur på feltet, evalueringsresultater fra gruppelærerdagene og våre egne erfaringer.

\section{GRUPPEL ERERDAGEN PÅ FAKULTET FOR NATURVITENSKAP OG TEKNOLOGI}

Det finnes ulike måter å organisere opplæring av gruppelærere [3]. Et ønske om et bærekraftig opplegg som ikke er for ressurskrevende verken nå eller i framtiden har i stor grad styrt valgene vi har tatt. Det bør være overkommelig og passe organiseringen av naturvitenskapene ved et relativt lite fakultet. Vi har valgt å organisere én opplæringsdag i begynnelse av hvert semester. Program for dagen varierer hver gang, slik at alle kan delta selv om man har deltatt før. Hovedmålgruppen er gruppelærere som underviser på bachelornivå i det aktuelle semesteret og vi har særlig ønsket å nå ut til emner i første studieår. Deltagelse på dagen er likevel åpen for alle på fakultetet. Vi har så langt arrangert tre opplæringsdager: Våren 2020, høsten 2020 og våren 2021 med henholdsvis 46, 66 og 39 påmeldte og 35,53 og 31 deltagere fra alle seks institutter på vårt fakultet. Cirka halvparten av påmeldte var bacheloreller masterstudenter, cirka en fjerdedel var stipendiater og resten besto stort sett av vitenskapelig ansatte i ulike stillingskategorier. 9 av 66 påmeldte til gruppelærerdagen høsten 2020 oppga at de hadde deltatt på gruppelærerdagen våren 2020. 19 av 39 påmeldte våren 2021 oppga at de hadde deltatt på minst én gruppelærerdag før.

Gruppelærernes utfordringer er annerledes enn utfordringer som andre undervisere erfarer og varierer i stor grad med erfaringsnivå [8,9], noe som bør tas høyde for i opplæringen [10]. For å legge til rette for en gruppe deltagere som er heterogen i erfaringsnivå, fag og undervisningsrolle har vi valgt å bygge opp gruppelærerdagene med en fellesdel og én (våren 2020) eller to (etter văren 2020) runder med valgfrie moduler. Gruppelærerdagen ble gjennomført fysisk våren $2020 \mathrm{og}$ digitalt deretter. I påmeldingene ba vi om forventninger til dagen og spesielle utfordringer de påmeldte hadde opplevd i sin undervisning. Disse forventningene, og spesielt utfordringene, har vi kommet inn på i fellesdelen. Diskusjon av utfordringene gjennom casediskusjoner i grupper på 3-4 deltagere med oppsummering i plenum har fått en stadig større plass i programmet. Utover dette har tema fra fellesdelen kommet tilbake som valgfri modul i neste gruppelærerdag slik at gjenbruk av økter ikke har gått på bekostning av de som deltar flere ganger. Temaer på gruppelærerdagene var: Forberedelse til gruppeundervisning og kommunikasjon med studentene og hvordan veilede studenter i oppgaveløsning; evaluering av undervisning og læring; studentaktiv læring i digital undervisning; tavlebruk og kroppsspråk; vurdering og retting av innleveringer; digitale verktøy for studentaktiv læring; hvordan håndtere umotiverte studenter; informatikkdidaktikk; code review og etiske problemstillinger. Gjennom dagene har vi fors $\varnothing \mathrm{kt}$ å introdusere og modellere ulike verktøy, undervisningsmetoder og -teknikker som er direkte anvendbar i gruppelærernes undervisning. I tillegg har vi lagt opp til et studentaktivt program, vel vitende at utbytte av dagen i stor grad påvirkes av deltagernes aktivitet og engasjement [10]. To gruppelærere var med i planlegging og gjennomføring av gruppelærerdagen og har delt sine erfaringer med henholdsvis studentevaluering og digital seminarundervisning. Våren 2021 begynte vi å samle ressurser som kan brukes av gruppelærere før og etter gruppelærerdagen. Ressursene er åpent tilgjengelig på uit.no/nt/kvant.

\section{UTBYTTE AV DAGEN}

I enkle evalueringer umiddelbart etter gruppelærerdagene har vi fors $\emptyset \mathrm{kt}$ å måle opplevd utbytte av dagen, samt hvordan dagen har påvirket gruppelærerens trygghet i sin rolle. For å evaluere den første gruppelærerdagen vår 2020 (og for å modellere en enkel og uformell evalueringsform) spurte vi deltagerne på begynnelsen og på slutten av dagen om hvor trygg de føler seg til å møte utfordringene i sin undervisning med en smilefjesskala på et stykke papir. Resultatene i Fig. 1 tyder på at dagen har bidratt til at i hvert fall noen gruppelærere føler seg tryggere. De fleste har opplevd at de har fått konkret utbytte som de kan ta med videre i sin undervisning. I skriftlige utdypninger om opplevd utbytte (som deltagerne kunne skrive under smilefjesene) ble alle deler av programmet nevnt minst én gang. Eksempler av konkret utbytte var «retting av oppgaver», «enkle studentaktive metoder som ikke krever mye planlegging å gjennomføre», «se etter om jeg faktisk klarer å engasjere studentene» og «hvordan å gi mest læringsutbytte når man hjelper studenter». Resultatene tyder på at det er stor variasjon blant deltagere om hvilken del av programmet gir mest utbytte, noe som kan forklares ut fra at ulikt erfaringsnivå gir ulike utfordringer [8] og at gruppelærerne har ulike undervisningsoppgaver. Med bakgrunn i disse resultatene $\varnothing \mathrm{kte}$ vi fra én til to runder med valgfrie moduler for videre gruppelærerdager. 
Hvor trygg føler du deg til å møte utfordringene i din undervisning?

I begynnelse av dagen

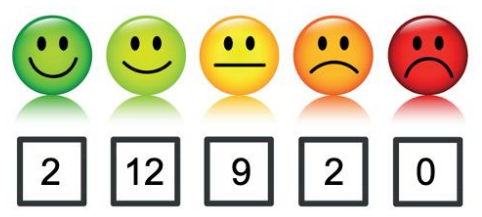

På slutten av dagen

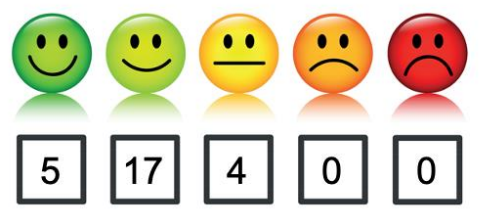

Har du fått konkret utbytte av dagen som du kan ta med videre i din undervisning?

Fig. 1. Evalueringsresultater fra gruppelarerdagen våren 2020.

Som evaluering av påfølgende gruppelærerdager ble en evaluering sendt ut til alle påmeldte tre dager etter gruppelærerdagen. Cirka halvparten av deltagerne (høsten 2020: 27 av 53; våren 2021: 17 av 31) svarte på evalueringen som besto av to spørsmål med mulighet for å utdype svarene. Resultatene i Tabell 1 dokumenterer at de aller fleste føler seg i hvert fall litt tryggere etter gruppelærerdagen. To utdypninger kommer flere ganger tilbake blant de som følger seg «litt» tryggere etter dagen. Noen utdyper at det ikke er en opplæringsdag, men heller erfaring som trenges for å bli tryggere i sin rolle: «tryggest blir man nok av ren erfaring». Flere andre utdyper at de allerede var ganske trygg i sin rolle som gruppelærer og opplevde dermed ingen stor forskjell, noe som igjen tyder på at utviklingsbehov for gruppelærerne avhenger av erfaringsnivå og at opplæringen bør ta høyde for det [8]. Resultatene dokumenterer videre at de aller fleste har middels eller mye utbytte av dagen. Utdypningene dokumenterer igjen stor variasjon $\mathrm{i}$ hvilken av delene som blir trukket fram som spesielt nyttig.

Tabell 1. Evalueringsresultater fra gruppelarerdagene hфsten 2020 og våren 2021.

Føler du deg tryggere i din rolle som gruppelærer etter å ha deltatt på gruppelærerdagen?

\begin{tabular}{|l|l|l|}
\hline & H2020 & V2021 \\
\hline Jeg føler meg ikke tryggere & $0(0 \%)$ & $2(12 \%)$ \\
\hline Jeg føler meg litt tryggere & $18(69 \%)$ & $10(59 \%)$ \\
\hline Vet ikke / nøytral & $3(12 \%)$ & $1(6 \%)$ \\
\hline Jeg føler meg mye tryggere & $4(15 \%)$ & $4(24 \%)$ \\
\hline Jeg føler meg svært mye tryggere & $1(4 \%)$ & $0(0 \%)$ \\
\hline
\end{tabular}

Hvor mye konkret utbytte har du hatt av dagen som du kan ta med videre i din undervisning?

\begin{tabular}{|l|l|l|}
\hline & H2020 & V2021 \\
\hline Svært lite & $0(0 \%)$ & $1(6 \%)$ \\
\hline Lite & $1(4 \%)$ & $1(6 \%)$ \\
\hline Middels & $15(56 \%)$ & $4(24 \%)$ \\
\hline Mye & $11(41 \%)$ & $9(53 \%)$ \\
\hline Svært mye & $0(0 \%)$ & $2(12 \%)$ \\
\hline
\end{tabular}

\section{DISKUSJON}

Vårt inntrykk ut fra organisering, gjennomføring og evaluering av gruppelærerdagene er at det er et tydelig ønske om et slikt opplæringstilbud. Vi ser at gruppelærerne har behov for og nytte av erfaringsdeling med andre gruppelærere, og vet at deltagelse i et fagfellesskap er en viktig del av en helhetlig pedagogisk opplæring [1,11]. Erfaringsutveksling blant gruppelærerne er nok likevel mest effektivt ved en fysisk gjennomføring av gruppelærerdagen, hvor ikke minst pausene bidrar til gode diskusjoner rundt undervisning. Dette ble også uttrykt som et savn i evalueringen da dagen gikk over til å bli digital. Vi håper og tror at gruppelærerdagen - om den er digital eller fysisk - fungerer som katalysator for mer erfaringsutveksling om undervisning og læring blant gruppelærere.

Vi mener at valgmodulene fungerer godt for å tilpasse opplæringen slik at det blir mest mulig relevant til gruppelærerne i ulike fag og med ulike undervisningsoppgaver. Noen gruppelærere hjelper stort sett med oppgaveløsning, mens andre har mer "klassisk" undervisning for eksempel med elementer av tavleundervisning. Noen gruppelærere deltar i stor grad i vurdering, mens andre ikke i det hele tatt. Noen gruppelærere underviser stort sett kun fysisk, mens andre også underviser digitalt. Vi ser det derfor som et positivt tegn at det er den store variasjonen i øktene som gruppelærerne rapporterer å ha mest utbytte av. 
Den første gruppelærerdagen var planlagt med undervisning i matematikk, fysikk og kjemi som utgangspunkt. Likevel viste det seg at cirka halvparten av påmeldte var bachelor- og masterstudenter som skulle undervise i informatikkemner. Vi fikk flere muntlige og skriftlige tilbakemeldinger på at deres behov ikke ble dekket i tilstrekkelig grad. De så relevans i det som ble presentert, men tilbakemeldingene var at de $\varnothing$ nsker mer konkret innhold rettet mot informatikk. I de påfølgende gruppelærerdagene har vi derfor hentet inn ekspertise fra en informatikkdidaktiker som tidligere har bidratt til fagspesifikke moduler i LAOS ved NTNU [7]. Informatikkdidaktikeren har bidratt med ulike valgmoduler som hadde mange deltagere og ble i evalueringen trukket fram av flere som $\varnothing$ kten som gav mest konkret utbytte.

For gruppelærerdagen ble det tatt et valg om at hovedspråket er norsk da de fleste underviser på norsk. Hovedmålgruppen er de som underviser på bachelornivå, særlig første år, og emnene på dette nivået undervises på norsk. Programmet for den første gruppelærerdagen var likevel delvis på engelsk og deltagerne kunne velge foretrukket språk i registreringen. Av de få registrerte deltagerne som ønsket et opplegg på engelsk (5 av 46) møtte ikke alle på selve dagen mens andre deltok også på delene på norsk. Noen av de valgfrie modulene som skulle holdes på engelsk ble likevel holdt på norsk siden alle deltagerne var norskspråklige. Høsten 2020 og våren 2021 var gruppelærerdagen utelukkende på norsk. Før og etter dagen fikk vi noen få tilbakemeldinger at gruppelærerne som ikke snakker norsk - alle stipendiater - også burde kunne delta. Vi valgte likevel å fortsette med et norskspråklig opplegg av flere grunner. For det første har stipendiater som nevnt tilgang til et kurs i universitetspedagogikk (som alternerer mellom norsk og engelsk) og dermed er gruppelærerdagen ikke det eneste opplæringstilbudet som finnes - i motsetning til studenter som underviser. Videre mener vi at det er viktig å snakke om undervisning på språket man underviser i, som er norsk for de aller fleste gruppelærerne. Vår erfaring er at de fleste gruppelærerne er mer komfortable med å snakke og dele erfaringer på norsk, noe som er særlig relevant å ta høyde for siden utbytte av opplæringen i stor grad er avhengig av deltageraktivitet [10]. Til slutt krever gruppelærere som ikke behersker norsk ofte tilpasning som er mer enn bare bytte av språk. Disse (internasjonale) gruppelærerne har nemlig ekstra behov bl.a. knyttet til deres tilpasning til det norske utdanningssystemet og eventuelle kulturforskjeller [5,12]. Det vil med andre ord gi mer mening å organisere en egen gruppelærerdag for internasjonale gruppelærere. En slik dag er planlagt midt i semesteret våren 2021.

Gruppelærerdagen har et begrenset omfang, og vi kan ikke forvente store følte endringer som resultat av én opplæringsdag. Vi er godt fornøyde med utbyttet som deltagerne rapporterer (Tabell 1). I de skriftlige evalueringene uttrykker flere at de gjerne skulle ha hatt mer tid satt av til de ulike temaene. Høsten 2020 var halvparten av svarene på spørsmålet «er det noe du har savnet eller har du forslag til organisering og temaer for neste gruppelærerdag?» knyttet til det tidsbegrensete omfanget av opplegget. Vår egen erfaring er også at det er krevende å selektere innhold for dagen ut fra alt som ville være nyttig for gruppelærerne. Likevel, som Meadows m.fl. [5] bemerker, er det lite sannsynlig at opplæring av gruppelærere blir et permanent tilbud om det er for tidskrevende. De finner i sin studie signifikant forbedring for undervisningen i et kondensert program ned i 20 timer, spesielt om oppfølgingen går over et lengere tidsintervall med mulighet for å anvende nye tilnærminger til undervisningen og til å reflektere over egen undervisning. For oss er det viktig å organisere gruppelærerdagen på en bærekraftig måte for å unngå at initiativet ikke videreføres fordi det krever for mye ressurser.

Gruppelærerdagen består, som navnet tilsier, kun av én dag med opplæring og erfaringsdeling per semester. Imidlertid er litteraturen tydelig på at det er viktig å ha kontinuerlig oppfølging [1,5]. Spesielt uerfarne undervisere har et stort behov for veiledning i undervisningsoppgavene [8]. Vi er klar over at gruppelærerne på vårt fakultet blir fulgt opp i svært ulik grad. I noen emner har gruppelærerne knapt kontakt med emnelederen, $i$ andre emner blir gruppelærerne fulgt opp tett gjennom ukentlige møter individuelt eller i grupper. Vi mener at oppfølging i de spesifikke undervisningsoppgavene, deltagelse i et sterkt lærerfellesskap lokalt og et mindre eller større kurs i universitetspedagogikk er viktige deler av en helhetlig oppfølging av gruppelærere [1,3,11]. I en oppfølgingsstudie ønsker vi å undersøke i hvilken grad og på hvilken måte gruppelærere blir fulgt opp, om de har fått anledning til å diskutere faglige og didaktiske utfordringer med mer erfarne (gruppe)lærere og om de selv føler et behov for slik oppfølging.

\section{KONKLUSJON}

Vi har dokumentert og diskutert et enkelt opplæringstilbud som tilbys i begynnelsen av hvert semester for ferske og mer erfarne gruppelærere ved vårt fakultet. Vi har kommet fram til et fast program som består av en fellesdel med fokus på utfordringene som deltagerne selv har sendt inn i kombinasjon med 
valgmoduler som tillater tilpasning til ulike fag og ulike undervisningsoppgaver. Tross begrenset omfang av tilbudet rapporterer de fleste gruppelærerne at de har fått konkret utbytte av dagen. Vi håper at dette bidraget kan inspirere andre til å ha mer fokus på opplæring av gruppelærere og gi verdifull innsikt til organisering av opplæringen. Samtidig ønsker vi å vise at dette ikke nødvendigvis må bli ressurskrevende for å utgjøre en forskjell for gruppelærerne, og forhåpentligvis også for undervisningskvalitet og studentenes læring.

\section{TAKK TIL}

Vi takker våre kollegaer som har bidratt til organisering og gjennomføring av gruppelærerdagene og deltagerne som har gitt tilbakemelding på opplegget.

\section{REFERANSER}

[1] Gardner, G. E. \& M. G. Jones (2011). Pedagogical preparation of the science graduate teaching assistant: Challenges and implications. Science Educator 20(2), 31-41.

[2] Hakel, K. (2017). Læringsassistenters plass i kvalitetssystemer. Uniped 40(01), 54-67. DOI: 10.18261/ISSN.1893-8981-2017-01-05

[3] Prieto, L. R. \& S. A. Meyers (Red.) (2001). The teaching assistant training handbook: How to prepare TAs for their responsibilities. Stillwater, Oklahoma, USA: New Forums Press.

[4] Goss Lucas, S. (2001). Departmental teaching assistants' orientation. In Prieto, L. R., \& S. A. Meyers (Red.). The teaching assistant training handbook: How to prepare TAs for their responsibilities (25-41). Stillwater, Oklahoma, USA: New Forums Press.

[5] Meadows, K. N., K. C. Olsen, N. Dimitrov, \& D. L. Dawson (2015). Evaluating the differential impact of teaching assistant training programs on international graduate student teaching. Canadian Journal of Higher Education 45(3), 34-55. DOI: 10.47678/cjhe.v45i3.187557

[6] Hakel, Katja. (2019). Learning assistants as key partners in the Scholarship of Teaching and Learning. Third EuroSoTL Conference: Exploring new fields through the scholarship of teaching and learning. ISSoTL, University of Pais Vasco (UPV); Bilbao. 2019-06-12 - 2019-06-14. URL: https://www.ehu.eus/documents/8301386/10560621/Actas-EuroSoTL-Conference-2019.pdf/1a7d5867e222-4aab-6f92-a7948f1fbd67, 522-530.

[7] Lorås, M. (2020). From teaching assistants to learning assistants-lessons learned from learning assistant training at Excited. Laring om laring 4(1). URL: https://www.ntnu.no/ojs/index.php/lol/article/view/3555

[8] Prieto, L. R. (2001). The supervision of graduate teaching assistants: Theory, evidence, and practice. In Prieto, L. R., \& S. A. Meyers (Red.). The teaching assistant training handbook: How to prepare TAs for their responsibilities (103-129). Stillwater, Oklahoma, USA: New Forums Press.

[9] Cho, Y., M. Kim, M. D. Svinicki \& M. L. Decker (2011). Exploring teaching concerns and characteristics of graduate teaching assistants. Teaching in Higher Education 16(3), 267-279. DOI: $10.1080 / 13562517.2010 .524920$

[10] Meyers, S. A. (2001). Conceptualizing and promoting effective TA training. In Prieto, L. R., \& S. A. Meyers (Red.). The teaching assistant training handbook: How to prepare TAs for their responsibilities (3-23). Stillwater, Oklahoma, USA: New Forums Press.

[11] Johansen, G. K. \& Beerepoot, M. T. P. (2019). På vei mot en kollegial tilnærming til undervisning seminarundervisning og pedagogisk opplæring av stipendiater. Nordic Journal of STEM Education 3(1), 3841. DOI: $10.5324 /$ njsteme.v3i1.2992

[12] Boman, J. S. (2013). Graduate student teaching development: Evaluating the effectiveness of training in relation to graduate student characteristics. Canadian Journal of Higher Education 43(1), 100-114. DOI: $10.47678 /$ cjhe.v43i1.2072 